\title{
Glycaemic Response of Traditional Breakfast Foods in Adults with Type 2 Diabetes Mellitus
}

\author{
M.P.M.S.H. Perera*, R. Sivakanesan ${ }^{1}$, D.T.D.J. Abeysekara ${ }^{2}$ and \\ K.H. Sarananda ${ }^{3}$ \\ Post Graduate Institute of Agriculture \\ University of Peradeniya \\ Sri Lanka
}

\begin{abstract}
Traditional Sri Lankan breakfast foods such as rotti, pittu, thosai, hopper and wandu made using $100 \%$ rice flour (RF) or $25 \%$ soy flour and $75 \%$ rice flour mixture (SFRF), alone or mixed with a mixed vegetable curry were tested for their available carbohydrate content (ACH) and Glycaemic index (GI). The mixed vegetable curry was prepared with Solanum melongena (eggplant), Solanum lycopersicum (tomato), Cucurbita maxima (pumpkin) and Ipomoea aquatica (kankun/water spinach). Rotti, pittu, thosai, hopper and wandu were analyzed for their ACH content by Megazyme assay kit. A total of 12, type 2 diabetic subjects participated in the GI study. The ACH of rotti, pittu, thosai, hopper and wandu made with RF were 45.2, 45.3, 41.8, 43.7 and 40.2 g/100g respectively without the curry, and 33.7, 35.0, 31.3, 32.9 and $28.2 \mathrm{~g} / 100 \mathrm{~g}$ with the vegetable mixed curry. The ACH of rotti, pittu, thosai, hopper and wandu made with SFRF were 28.5, 28.0, 25.5, 29.0 and $23.0 \mathrm{~g} / 100 \mathrm{~g}$ respectively without the curry, and 22.5, 25.9, 21.8, 24.0 and 20.4 $\mathrm{g} / 100 \mathrm{~g}$ with the vegetable mixed curry. Addition of vegetable mixed curry showed significant reduction $(\mathrm{p}<0.05)$ in ACH content of all test meals. GI of rotti, pittu, thosai, hopper and wandu made with SFRF were 54.4, 51.4, 50.1, 49.3 and 45.1 respectively and hence could be considered as low GI foods. The present study showed that substitution of rice flour with $25 \%$ soy flour in a mixed meal reduced the post prandial blood glucose response in diabetics. Consumption of rotti, pittu, thosai, hopper and wandu made with SFRF and mixed vegetable curry together might be beneficial in the dietary management of type 2 diabetes.
\end{abstract}

Keywords: Available carbohydrate, diabetes mellitus, Glycaemic index, mixed vegetable curry

\section{INTRODUCTION}

Non-Communicable Diseases (NCDs) including diabetes mellitus, have been on the rise in the past two decades in Sri Lanka and at present are the leading cause of mortality, morbidity, and disability (Annual Health Bulletin, 2012). Government hospital statistics indicates that $71 \%$ of all annual deaths in Sri Lanka is due to chronic NCDs (Annual Health Bulletin 2012). It is widely believed that the NCD epidemic in the country is particularly associated with unhealthy dietary habits $(82.4 \%)$, physical inactivity $(25 \%)$ and overweight

\footnotetext{
Department of Biochemistry, Faculty of Medicine, University of Peradeniya, Peradeniya, Sri Lanka.

Lakeside Adventist Hospital, Kandy, Sri Lanka.

Food Research Unit, Department of Agriculture, Gannoruwa, Peradeniya, Sri Lanka.

* Corresponding author: mpmshpp@yahoo.com
} 
and obesity (25\%) (Annual Health Bulletin 2012). In 2005, the prevalence of diabetes mellitus in Sri Lanka was 10.3\% among adults (Katulanda et al., 2008). In 2012 the percentage of population having their fasting blood glucose concentration above $126 \mathrm{mg} / \mathrm{dl}$ was $14.12 \%$ and percentage detected among the women screened at Well Woman Clinic for diabetes mellitus was $2 \%$ (Annual Health Bulletin. 2012). According to the Indoor Morbidity and Mortality Statistics by Broad Disease Groups in 2012, out of 78,900 diabetic subjects in the country, 675 cases of mortality were reported (Annual Health Bulletin, 2012). The goal of diabetes management is to keep blood glucose concentrations close to normal $\left(\mathrm{HBA}_{1} \mathrm{C}<7\right.$ $\%$ ) to delay the onset and progression of complications (Canadian Diabetes Association Clinical practice Guidelines Expert Committee, 2013).

After overnight fast, breakfast must provide readily-available energy to allow coping with the morning activities and those of the day. Eating a healthy breakfast decreases the risk of developing type 2 diabetes. Skipping breakfast is associated with weight gain, one of the main risk factors for type 2 diabetes. (World Diabetes Day 2014 GuideBook, 2014). Low glycaemic foods modulate the glucose response and keep the energy levels balanced, preventing 'energy dips' as well as providing long satiety between meals within a whole day (Clark et al., 2006: Mark et al., 2011).

Low GI breakfast foods composed of lente carbohydrates from whole grain cereals and legumes, plant protein and bioactive components is reported to result in a reduced oxidative stress and lower postprandial glucose excursion (David et al., 2003).

Generally Sri Lankans consume the largest starch portion for lunch or dinner, nearly $65 \%$ consume well above the upper cutoff of the recommendation for carbohydrates. Moreover, average daily intake of fruits and vegetables is low. Furthermore, 36.2\% consumed the minimum protein recommendation for Sri Lankans. It was evident that a substantial proportion of Sri Lankans do not consume a balance diet. As a result, a close association between unhealthy dietary intake and NCDs was reported (Jayawardhana et al., 2012).

Therefore, the purpose of this study was to analyze the available carbohydrate content of rotti, pittu, thosai, hopper and wandu made with either $100 \%$ rice flour or $25 \%$ soy flour and $75 \%$ rice flour mixture consumed with vegetable mixed curry prepared using Solanum melongena (eggplant), Solanum lycopersicum (tomato), Cucurbita maxima (pumpkin), Ipomoea aquatica (water spinach/kankun) and to investigate the potential postprandial blood glucose lowering effect, in Sri Lankan type 2 diabetic adults.

\section{MATERIAL AND METHODS}

\section{Preparation of soy bean flour and rice flour}

Raw rice (Bg-352) was obtained from Rice Research and Development Institute, Bathalagoda. Soy bean (Pb-1) seeds were obtained from Palwehera Farm, Department of Agriculture, Dambulla. Preparation of rice flour and soy bean flour were carried out according to the procedure of Perera et al. (2014).

\section{Preparation of breakfast foods and vegetable mixed curry}

Preparation of rotti, pittu, thosai, hopper, wandu (test foods) and vegetable mixed curry has been described earlier (Perera et al., 2014). 


\section{Determination of available carbohydrate (ACH) content of test foods}

Five test foods made with either $100 \%$ rice flour (RF) or $25 \%$ soy flour and $75 \%$ rice flour mixture (SFRF) alone or mixed with vegetable mixed curry were analyzed for available carbohydrate using the method of McCleary et al., (2006) using Megazyme assay kit (Megazyme International Ireland, Bray, Ireland).

\section{Ethical clearance}

Approval for the study was obtained from the Ethical Review Committee, Faculty of Medicine, University of Peradeniya, Sri Lanka (2012/EC/09).

\section{Selection of study subjects for Glycaemic Index study}

A group of non-smoking type 2 diabetic adults $(n=12)$ including both sexes (six females and six males) between 36 to 60 years of age and mean body mass index (BMI) of 23.51 2.2 $\mathrm{kg} / \mathrm{m}^{2}$ was selected. Study subjects with food allergy and chronic diseases except type 2 diabetes mellitus were excluded from the study. Eleven of the subjects were treated with Metformin 500 to $750 \mathrm{mg}$ twice a day and only one study subject was treated with Insulin 20 units twice a day as prescribed by the Physician. The duration of diabetes varied from 2 to 18 years. Study procedure was explained and written consent was obtained from each subject before initiation of the experiment. The subjects were instructed not to take alcohol and engage in heavy physical activity the day before the test.

\section{Determination of Glycaemic Index (GI)}

Determination of GI was carried out by the method of Brouns et al., (2005), Thomas et al., (1991). Blood samples were taken under aseptic conditions. After a $12 \mathrm{~h}$ overnight fast, between 7:30 and 8:30 AM a baseline fasting finger prick capillary blood sample was taken 15 minutes before initiation of the GI study. The subjects were given rotti, pittu, thosai, hoppers and wandu made with $25 \%$ soy flour and $75 \%$ rice flour and vegetable mixed curry containing $50 \mathrm{~g}$ of available carbohydrate as test meal along with $250 \mathrm{ml}$ of boiled cooled drinking water. D-Glucose $50 \mathrm{~g}$ was given as the reference food (Bio Labs, Veyangoda, Sri Lanka). The subjects were instructed to consume the food completely and finish within 10 min. Following consumption of the test or reference food, capillary blood samples were collected at 30 minutes intervals for $3 \mathrm{~h}$. Capillary blood glucose concentration was measured immediately after collection using a Glucometer (Optium XceedTM; Woodley equipment company Ltd, Lancashire, United Kingdom).

\section{Calculation of GI}

The incremental area under the curve (IAUC) was calculated by using the trapezoidal method (Brouns et al., 2005). The area under the glycaemic response curve for each food was expressed as a percent of the mean response to the standard food taken by the same subject, and the resulting values were averaged to obtain the GI value of each test meal. IAUC of test meals and reference food were constructed and calculation of GI was done using Microsoft Office Excel 2007 computer package. GI values of foods were expressed as the mean \pm SD. 


\section{Statistical analysis}

Duncan's Multiple Range Test (DMRT) was performed to compare means of ACH content. The means of the GI values of test meals were compared using student ' $t$ ' test. SPSS statistical software version 14 (SPSS inc., USA) was used to analyze data and the difference was considered significant at $\mathrm{p}<0.05$.

\section{RESULTS AND DISCUSSION}

\section{Demographic data of study subjects}

Age, Body Mass Index (BMI), systolic blood pressure (SBP), diastolic blood pressure (DBP), fasting blood glucose concentration (FBG), random blood glucose concentration (RBG) and glycated hemoglobin percentage $\left(\mathrm{HBA}_{1} \mathrm{C}\right)$ of study subjects are given in Table 1.

Two females and two male subjects had their FBG $<120 \mathrm{mg} / \mathrm{dl}$. Seven subjects had FBG $<$ $200 \mathrm{mg} / \mathrm{dl}$ and only one had $200 \mathrm{mg} / \mathrm{dl}$. Three males and three female subject had RBG $<160$ $\mathrm{mg} / \mathrm{dl}$. Five subjects had $<200 \mathrm{mg} / \mathrm{dl}$ of RBG and only one subject had $>200 \mathrm{mg} / \mathrm{dl}$.

Table 1. Demographic data of study subjects

\begin{tabular}{lcc}
\hline & Mean \pm SD & Range \\
\hline Age (years) & $49.5 \pm 8.7$ & $36-60$ \\
BMI & $23.5 \pm 2.2$ & $18-24$ \\
SBP $(\mathrm{mm} / \mathrm{Hg})$ & $119.0 \pm 5.8$ & $110-130$ \\
DBP $(\mathrm{mm} / \mathrm{Hg})$ & $79.5 \pm 3.7$ & $70-85$ \\
FBG $(\mathrm{mg} / \mathrm{dl})$ & $147.3 \pm 39.5$ & $92-200$ \\
RBG $(\mathrm{mg} / \mathrm{dl})$ & $162.6 \pm 36.9$ & $136-225$ \\
$\mathrm{HBA}_{1} \mathrm{C}$ & $6.9 \pm 0.7$ & $6-8$ \\
\hline
\end{tabular}

Four females and three males showed acceptable glycaemic control $\left(\mathrm{HBA}_{1} \mathrm{C}<7.0 \%\right)$ while others had unsatisfactory glycaemic control $\left(\mathrm{HBA}_{1} \mathrm{C}>7.0 \%\right)$.

\section{Available carbohydrate content of rotti, pittu, thosai, hopper and wandu made with RF}

The available carbohydrate content of rotti, pittu, hopper, thosai and wandu made with $100 \%$ rice flour with and without curry are given in Table 2 . The amount of carbohydrate obtained 'by difference' in our laboratory previously (Perera et al., 2014) was significantly high $(\mathrm{p}<0.05)$ compared to the amount of ACH determined by Megazyme assay kit.

Pittu had the highest available carbohydrate content $(45.3 \mathrm{~g} / 100 \mathrm{~g})$ while wandu had the lowest $(40.2 \mathrm{~g} / 100 \mathrm{~g})$. Addition of vegetable mixed curry showed nearly $25 \%$ reduction in the available carbohydrate content among all food items tested and was significant $(\mathrm{p}<0.001)$. Pittu and vegetable mixed curry had the highest $(35.0 \mathrm{~g} / 100 \mathrm{~g}) \mathrm{ACH}$ while wandu and vegetable curry had the lowest amount of ACH $(28.2 \mathrm{~g} / 100 \mathrm{~g})$. 
Table 2. Available carbohydrate content of rotti, pittu, hopper, thosai and wandu made with RF taken alone and with vegetable mixed curry

\begin{tabular}{|c|c|c|c|c|}
\hline \multirow[b]{2}{*}{$\begin{array}{l}\text { Name of } \\
\text { the food } \\
\text { item }\end{array}$} & \multicolumn{3}{|c|}{$*$ Mean \pm SD of constituents $(\mathrm{g} / 100 \mathrm{~g})$} & \multirow[b]{2}{*}{$\begin{array}{c}\text { Difference ir } \\
\text { mean ACH } \\
\text { content }\end{array}$} \\
\hline & $\begin{array}{l}\text { Carbohydrate } \\
\text { (by difference) }\end{array}$ & $\begin{array}{c}\text { ACH without } \\
\text { curry }\end{array}$ & ACH with curry & \\
\hline Pittu & $46.8^{\mathrm{a}}$ & $45.26 \pm 0.80^{\mathrm{a}}$ & $34.97 \pm 0.70^{\mathrm{a}}$ & 10.29 \\
\hline Rotti & $49.9^{\mathrm{b}}$ & $45.17 \pm 1.37^{\mathrm{a}}$ & $33.67 \pm 0.93^{\mathrm{ab}}$ & 11.50 \\
\hline Hopper & $49.1^{\mathrm{c}}$ & $43.62 \pm 0.87^{b}$ & $32.87 \pm 1.27^{\mathrm{b}}$ & 10.75 \\
\hline Thosai & $45.5^{\mathrm{d}}$ & $41.75 \pm 0.99^{c}$ & $31.32 \pm 1.14^{\mathrm{c}}$ & 10.43 \\
\hline Wandu & $46.0^{\mathrm{e}}$ & $40.21 \pm 0.57^{\mathrm{d}}$ & $28.17 \pm 0.98^{\mathrm{d}}$ & 12.04 \\
\hline$p$ & $<0.001$ & $<0.001$ & $<0.001$ & \\
\hline
\end{tabular}

* Treatment means in a column having common letter(s) are not significantly different by DMRT 5\% Each data point represents the mean of triplicates in 3 replicates

$\mathrm{ACH}=$ Available carbohydrate content.

Available carbohydrate content of rotti, pittu, hopper, thosai and wandu made with SFRF taken alone or with vegetable mixed curry

The ACH content of rotti, pittu, hopper, thosai and wandu made with $75 \%$ rice flour and $25 \%$ soy flour mixture taken alone and with vegetable mixed curry are given in Table 3 . The amount of carbohydrate reported 'by difference' (Perera et al., 2014) was significantly high $(\mathrm{p}<0.001)$ compared with the amount of $\mathrm{ACH}$ obtained by enzymatic digestion method. Hopper had the highest available carbohydrate content $(29.0 \mathrm{~g} / 100 \mathrm{~g})$ while wandu had the lowest $(23.0 \mathrm{~g} / 100 \mathrm{~g})$. Pittu vegetable mixed curry mixture had the highest ACH content $(25.8 \mathrm{~g} / 100 \mathrm{~g})$ while wandu vegetable curry mixture $(28.2 \mathrm{~g} / 100 \mathrm{~g})$ had the lowest amount of $\mathrm{ACH}$. Addition of vegetable mixed curry showed significant reduction $(\mathrm{p}<0.001)$ in the ACH content. The reduction was highest in rotti vegetable mixed curry mixture and the lowest was observed in pittu vegetable mixed curry mixture.

Table 3. Available carbohydrate content of rotti, pittu, hopper, thosai and wandu made with SFRF taken alone and with vegetable mixed curry

\begin{tabular}{ccccc}
\hline \multirow{2}{*}{$\begin{array}{l}\text { Name of } \\
\text { the food } \\
\text { item }\end{array}$} & $\begin{array}{c}\text { Carbohydrate } \\
\text { (by difference) }\end{array}$ & $\begin{array}{c}\text { ACH without } \\
\text { curry }\end{array}$ & $\begin{array}{c}\text { ACH with } \\
\text { curry }\end{array}$ & $\begin{array}{c}\text { Difference in mean } \\
\text { carbohydrate } \\
\text { content }\end{array}$ \\
\hline Pittu & $29.3 \pm 2.0^{\mathrm{a}}$ & $28.0 \pm 1.6^{\mathrm{a}}$ & $26.0 \pm 1.53^{\mathrm{a}}$ & 2.14 \\
Rotti & $36.9 \pm 2.7^{\mathrm{b}}$ & $28.5 \pm 1.4^{\mathrm{ab}}$ & $22.5 \pm 2.32^{\mathrm{b}}$ & 6.02 \\
Hopper & $33.2 \pm 2.5^{\mathrm{c}}$ & $29.0 \pm 1.0^{\mathrm{b}}$ & $24.0 \pm 1.56^{\mathrm{c}}$ & 4.96 \\
Thosai & $27.8 \pm 2.5^{\mathrm{d}}$ & $25.5 \pm 0.9^{\mathrm{c}}$ & $21.8 \pm 0.86^{\mathrm{db}}$ & 3.73 \\
Wandu & $32.2 \pm 1.7^{\mathrm{e}}$ & $23.0 \pm 1.2^{\mathrm{d}}$ & $20.4 \pm 0.72^{\mathrm{d}}$ & 2.60 \\
$p$ & $<0.001$ & $<0.001$ & $<0.001$ & \\
\hline
\end{tabular}

*Treatment means in a column having common letter(s) are not significantly different by DMRT 5\%

Each data point represents the mean of triplicates in 3 replicates

$\mathrm{ACH}=$ Available carbohydrate content

Variability in available carbohydrate content of test foods made with different flour types alone or with vegetable mixed curry are presented in Figure 1. 


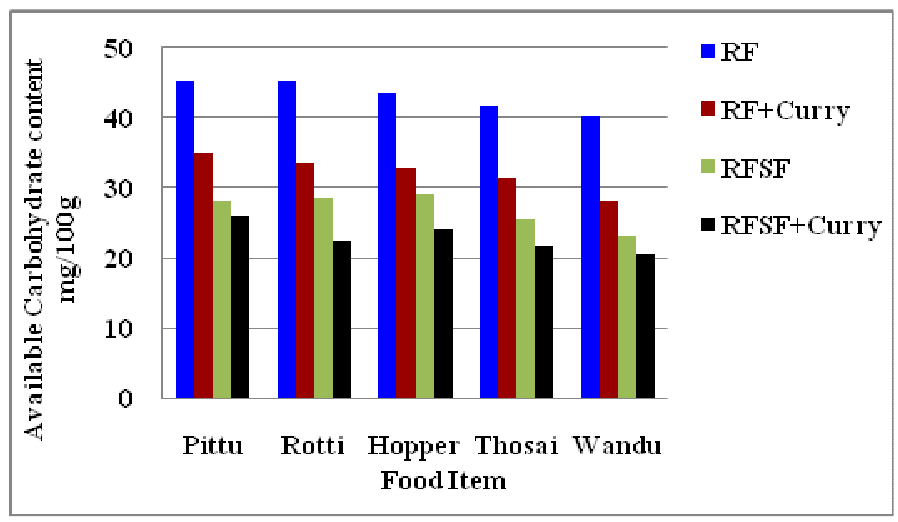

Fig. 1. Variability in available carbohydrate content of test foods

Francis et al. (1987) showed that foods providing equi-carbohydrate portions can produce different postprandial glycaemic response. A number of factors such as nature, source of starch, the physical form of food, methods of processing or cooking, starch-nutrient interactions, dietary fiber and anti-nutrients have been implicated in post prandial glycaemia (David et al., 1982). Mani et al. (1992) explained that starch granules in cereal grains are structurally different from those in legume seeds. Differences in particle size and surface area result in altered digestion by hydrolytic enzymes (David et al., 1982). The ratio of amylose:amylopectin affect the physical characteristics of the starch both with regard to its response to cooking and its digestibility. Soy contains 5-10\% more amylose, which is more resistant to cooking and digestion, than amylopectin, than do rice. The fiber in soy is more viscous than in cereals ( $\mathrm{Ji}$ et al., 2008). ACH content of test meals made by incorporating $25 \%$ soy flour was lower than the ACH of test meals made with RF consumed alone or with vegetable mixed curry. Dietary fiber present in vegetables inhibits starch digestibility further by packing the carbohydrate and insulating it from digestive enzymes which could also be the reason for the lower available carbohydrate content observed in the present study.

\section{GI of rotti, pittu, hopper, thosai and wandu made with SFRF consumed with vegetable mixed curry}

In general the meals were well received and were finished in 10 to $15 \mathrm{~min}$. No preference was expressed for a particular type of food. Glycaemic index has been proposed as a way of classifying carbohydrate containing foods according to blood glucose responses. GI of pittu, rotti, wandu, hopper and thosai made with $25 \%$ soy flour and $75 \%$ rice flour and mixed vegetable curry mixture obtained in healthy adults in a previous study were low $(35.5 \pm 9.8$, $36.0 \pm 8.1,43.0 \pm 8.9,45.2 \pm 8.6$ and $47.3 \pm 5.3$ respectively) (Perera et al., 2014) compared to the GI values obtained in this study. All foods tested in the present study in type 2 diabetic adults showed GI values between 49.3 to 54.4 hence could be considered as low GI foods (GI< 55 low GI) (Perera et al., 2014) (Table 4). 
Table 4. GI of rotti, pittu, hopper, thosai and wandu made with $25 \%$ soy flour and $75 \%$ rice flour consumed with vegetable mixed curry

\begin{tabular}{cc}
\hline Food item & *GI in type 2 diabetic adults \\
\hline Pittu & $51.38 \pm 11.00^{\mathrm{a}}$ \\
Rotti & $54.39 \pm 8.48^{\mathrm{b}}$ \\
Wandu & $45.11 \pm 8.30^{\mathrm{c}}$ \\
Hopper & $49.30 \pm 11.51^{\mathrm{d}}$ \\
Thosai & $50.07 \pm 6.75^{\mathrm{e}}$ \\
\hline *GI of food items given in a column having different superscripts are significant different by ' $\mathrm{t}$ ' test (p<0.05)
\end{tabular}

David et al. (1982) showed that meals containing legumes raise the blood glucose less than meals of the same carbohydrate content from other sources. Thomas et al. (1991) demonstrated that when fat is added to a carbohydrate meal it reduces glycaemic response by slowing gastric emptying rather than modifying starch availability. In addition mechanical barriers such as protein matrix that encapsulates gelatinized starch granules limit access to amylase and reduces starch availability (David et al., 2003: Anette et al., 1995). The amount of fat and protein in soy flour used to make all test food items were between 21.7 and 38.4 $\mathrm{g} / 100 \mathrm{~g}$ dry weight respectively (Perera et al., 2014). Furthermore, starch found in legumes has high amylose content, which is a determinant factor of starch hydrolysis. Therefore high amylase rice contributes to a reduced glycaemic response in comparison with low amylose rice (David et al., 1980). The present study showed that substitution of rice flour with $25 \%$ of soy flour in a mixed meal reduced the post prandial blood glucose response and our results are in accordance with other studies (Hong et al., 2005; Zahabazian et al., 2006; Alan et al., 1986: Ji et al., 2008 and Yukako et al., 2013).

During the study period the mean fasting blood glucose concentration of study subjects varied between 131.2 to $164.8 \mathrm{mg} / \mathrm{dl}$ (Fig. 2). Rotti and pittu increased the blood glucose response more than that of thosai, hopper and wandu. The mean peak blood glucose concentration was 243.7 for rotti at $90 \mathrm{~min}$ and $250.9 \mathrm{mg} / \mathrm{dl}$ for pittu at $60 \mathrm{~min}$ and this was significantly higher $(\mathrm{p}<0.000)$ than $202.2,210.4$ and $200.1 \mathrm{mg} / \mathrm{dl}$ for hopper, thosai and wandu respectively. The mean peak rise in blood glucose for D-glucose was observed at 60 min which was $325.1 \mathrm{mg} / \mathrm{dl}$ whereas all foods tested showed significantly low $(\mathrm{p}<0.001)$ peak mean blood glucose concentrations compared to D glucose at 60 min except rotti meal.

At $120 \mathrm{~min}$, mean peak rise in blood glucose for glucose was higher $(260.36 \mathrm{mg} / \mathrm{dl})$ whereas rotti, pittu, hopper, thosai, and wandu showed significantly low $(\mathrm{p}<0.001)$ mean peak blood glucose concentrations $(224.55,220.64,189.45,198.18,183.0 \mathrm{mg} / \mathrm{dl}$ respectively).

After dietary intervention at 180 min all study subjects showed random blood glucose concentration between 130 to $180 \mathrm{mg} / \mathrm{dl}$ which is considered as good control for people with type 2 diabetes.

However this study was not repeated because of the need for blood drawing for which the consent given by the subjects was not satisfactory. 


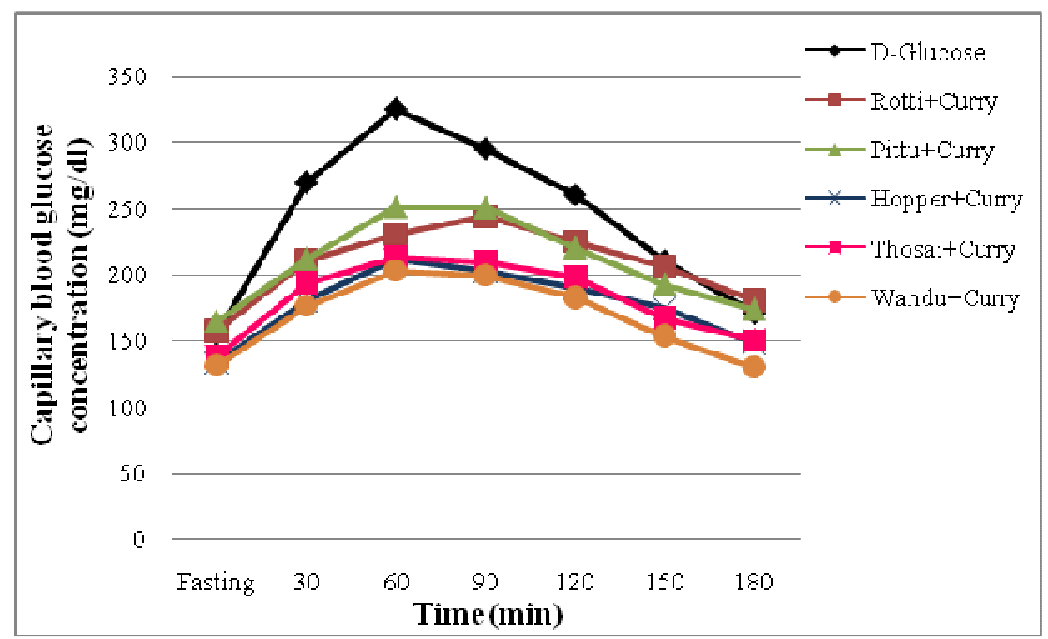

Fig. 2. Capillary blood glucose response curve for D-Glucose, rotti, pittu, thosai, hopper and wandu consumed with vegetable mixed curry

\section{CONCLUSIONS}

The findings revealed that rotti, pittu, thosai hopper and wandu made with a mixture of $25 \%$ soy flour $75 \%$ rice flour mixture and consumed with vegetable mixed curry had low post prandial blood glucose response in type 2 diabetics. Thus it could be concluded that ingesting soy incorporated traditional breakfast foods with vegetable mixed curry improves the post load glycaemic response in diabetics. Therefore, the five test meals might be beneficial in the dietary management of type 2 diabetes.

\section{ACKNOWLEDGEMENTS}

This research work has been supported by funding from the Postgraduate Institute of Agriculture, University of Peradeniya (RFF 2013). We sincerely thank all participants and specially the Chief Assistant Managing Officer at the Office of The Senior Superintend of Police in Kandy, granting permission to use their staff as study subjects and allowing to collect blood samples for the study. Finally we thank Rice Research and Development Institute, Bathalagoda for providing raw materials for the study.

\section{REFERENCES}

Alan, C. Tasi., Arthur, I. Vinik., A. Lasichak. and Grase, S. Lo. (1987). Effect of soy polysaccharide on postprandial glucose, insulin, glucagon, pancreatic polypeptide and triglyceride in obese diabetic patients. Am. J. of Clin. Nutr., 45, 596 - 601

Anette, E. Jarvi., Brita, E. Karistrom., Yvonne, E. Garnfeldt., Inger, M.E. Bjorck., Bengt O.H. Vessby. and Nils-george L. Am. J. of Clin. Nutr., (1995). The influence of food structure on postprandial metabolism in patients with non-insulin dependent diabetes mellitus. 61, 837 - 842. 
Annual Health Bulletin.(2012). Medical Statistical Unit. Ministry of Health. Sri lanka.

Brons, F. Bjorck, I. and Wloever, T.M.S. (2005). Glycaemic Index Methodology. Nutr. Res. Rev., 18, 145 - 171.

Canadian Diabetes Association Clinical practice Guidelines Expert Committee. (2013). Clinical Practice Guidelines Nutrition therapy. Can. J. of Diabetes. 37, S45 - S55.

Clark, C.A., Gardiner, J., Mcburney, M.I. and Hord, N.G. (2006). Effects of breakfast meal composition on second meal metabolic responses in adults with type 2 diabetes mellitus. EUR J. of Clin. Nut., 60, 1122 - 1129.

David, J.A. Jenkins., Thomas, M.S. Wolever., Rodney, H. Taylor., Hamid, Ghafari., Alexandra, 1. Jenkins., Helen, barker. and Mark, J.A. Jenkins. (1980). Rate of digestion of foods and postprandial glycaemia in normal and diabetic subjects. Br. Med. J., 5, 14-17.

David, J.A. Jenkins., Mary, Jane, Throne., Kathy, Camelon., Alexandra, 1.Jenkins., Rodney, H. Taylor. and Thomas, Francis. (1982). Effects of processing on digestibility and the blood glucose response: a study of lentils. Am. J. of Clin. Nutr., 36, 1093 - 1101.

David, J.A. Jenkins., Thomas, M.S. Wolever., Rodney, H. Taylor., David, L. Sarson. and Stephen, R. Bloom. (1982). Slow release dietary carbohydrate improves second meal tolerance. Am. J. of Clin. Nutr.,.35, 1339 - 1346.

David, J.A. Jenkins., Cyril, W.C. Kendall., Augustine, Marchie., Alexandra, 1. Jenkins., Livia S.A. Augustine. and James, W. Anderson. (2003). Type 2 diabetes and the vegetarian diet. Am. J. of Clin. Nutr.,. 6, 610S - 615S.

Francis, R.J. Bronte., Dominique, Costangliola., Salwa, W. Rizkalla. and Gerard Salma. (1987). Insulinemic and glycaemic indexes of six starch-rich foods taken alone and in a mixed meal by type 2 diabetics. Am. J. of Clin. Nutr.,. 45, 588 - 595.

Ji, Ho Chang., min, Sun, Kim., Tae, Eha, Kim. and Sang, Sun, Lee. (2008). Effects of soybean supplementation on blood glucose, plasma lipid levels, and erythrocyte antioxidant enzyme activity in type 2 diabetes mellitus patients. Nutr. Res. Pract., 2(3). 152 - 157.

Katulanda, P., Constantine, G.R., Mahesh, J.G., Sheriff, R., Senevirathna, R.D., Wijerathne, S., Wijesuriya, M., McCarthy, M.I., and Matthews, D.R. (2008). Prevalence and projection of diabetes and pre-diabetes in adults in Sri lanka - Sri Lanka Diabetes, Cardiovascular Study. Diabetes Medicine, 9, 1062 - 1069.

Mani, U.V., Pradhan, S.N., Metha, N.C., Thakur, D.M., Iyer, U. and Mani, I.(1992). Glycaemic index of conventional carbohydrate meals, Br. J. Nutr., 68, 445 - 450.

McCleary, B.V. and P.C. Rossiter, (2006). Dietary fibre and glycaemic carbohydrates. In Dietary Fiber and its Energy Value D.T. Gordon and T. Goda, Eds., Egan Press, AACC International. 
Perera, M.P.M.S.H., Sivakanesan, R. Abeysekara D.T.D.J. and Sarananda, K.H. (2014). Sensory evaluation, Proximate Composition and Available Carbohydrate Content of Soy Flour Incorporated Cereal Based Traditional Sri Lankan Breakfast Foods. Int. J. Res. Agric. Food Sci., 1,10 - 18.

Perera, M.P.M.S.H., Sivakanesan, R. Abeysekara D.T.D.J.and Sarananda, K.H., (2014). Effect of Vegetable Mixed Curry on Glycaemic Index and Glycaemic Load of Soy Flour Incorporated Traditional Sri Lankan Breakfast Foods in Healthy Adults. Pak. J. Nutr., 13, $611-621$.

Ranil, jayawardhana., Naula, M. Byrne., Mario, J. Soarse Prasad, Katulanda. and Andrew P. Hills. Food consumption of Sri Lankan adults.(2012). Public Health Nutr., 16, 653 - 658.

Thomas, M.S.Wolever., Devid, J.A.Jenkins., Alexandra, 1.Jenkins. and Robert, G. Josse. (1991). The glycaemic Index: methodology and clinical implications. Am. J. of Clin. Nutr., $54,846-854$.

World Diabetes Day 2014 GuideBook 2014. International Diabetes Federation.

Yukako, tatsumi., Akiko, morimoto., Kijyo, Deura., shochi, Mizuno., Yuko, Ohno. and Shaw, Watanabe. (2013). Effects of soybean product intake on fasting and postload hyperglycaemia and type 2 diabetes in Japanese men with high body mass index: The sake Study. J. Diabetes Investig., 4, 626 - 635.

Zahabazian, H.B., Amani, R. and Haghighizadeh, M. (2006). Beneficial effects of soyprotein isoflavons on lipid and blood glucose concentrations in type 2 diabetic subjects. Jundishapur J. Nat. Pharm. Prod.,1, 48 - 52. 